\title{
Protection of Dance's Copyright (Study on Conception and Regional Government's Effort to Protect Topeng Ireng Dance in Magelang, Indonesia)
}

\author{
Meiana Pindy Hapsari, Andry Wijayanto, Hasna Ratifah, Chrisna Bagus Edhita Praja* \\ Faculty of Law, Universitas Muhammadiyah Magelang, Mayjend Bambang Soegeng Street, km.5, Mertoyudan, \\ Magelang, Indonesia
}

The research is financed by the Ministry of Education and Culture of Indonesia through the Student Creativity Program-Social Humanities Research (PKM-RSH)

\section{Abstract}

This study aims to identify the pattern of legal protection conducted by the Regional Government of Magelang Regency against the Topeng Ireng dance art. This study uses empirical juridical research with primary data from field data obtained from interviews with the Topeng Ireng Dance Community, the Education and Culture Office of Magelang Regency, and the Association of Indonesian Intellectual Property Centers (ASKII). Secondary data was obtained from primary legal materials in the form of Copyright Law of 2014 and Law Number 5 of 2017 concerning the Advancement of Culture. The data obtained were then analyzed qualitatively and presented descriptively. The results showed that the Topeng Ireng dance meets the requirements as work and deserves copyright protection. The protection of the Topeng Ireng dance is in the form of preventive legal protection by taking inventory, development, utilization and guidance. Repressive legal efforts have not been implemented because until present, no claims have been found by other parties against the Topeng Ireng dance. However, if this condition occurs, the local government of Magelang Regency will immediately act by filing a lawsuit to the Commercial Court accompanied by concrete evidence in the form of publication videos, history books of the establishment of the Topeng Ireng dance, activity inventory books and witnesses from the Topeng Ireng community. The factors that influence the implementation of the protection of the Topeng Ireng dance consist of regulatory factors, law enforcement, facilities that support law enforcement, society, and culture.

Keywords: Topeng Ireng Dance Art, Legal Protection, Copyrights of art

DOI: $10.7176 / \mathrm{JLPG} / 116-03$

Publication date: December $31^{\text {st }} 2021$

\section{INTRODUCTION}

Art is part of the cultural tradition of the people who always live as a form of personal or group expressions (Najah and Malrsih, 2019). Dance is one type of art and cultural statement to express the soul through body movements with a certain rhythm. Therefore, the nature, style and function of dance always cannot be separated from the culture that produces it. Currently, there is a paradigm change occurring in the art of dance, which began as an expression of artistic expression but has expanded to include cultural and economic aspects (Djuhara, 2014).

Dance is one of the objects of Intellectual Property Rights which is protected in Law Number 28 of 2014 (UUHC). The issue of intellectual property rights is often a hot issue, especially in terms of traditional arts. Numerous occurrences involving neighboring countries claiming Indonesian artworks demonstrate a lack of public understanding and awareness, as well as the government's efforts to protect intellectual property rights. Intellectual property can actually be protected by using legal instruments such as copyright. In addition, efforts to protect traditional arts can also be done by publicizing the culture as widely as possible. The emergence of several issues in the area of intellectual property rights demonstrates that the ideals underlying the protection of indigenous culture have not been fully implemented to yet (Astar, 2017). Therefore, the diverse cultures that exist in Indonesia are in dire need of a protection effort, especially legal protection in it as an intellectual property (Hapsari, 2013).

Topeng Ireng Dance is a traditional art from Magelang, Indonesia that originated during the Japanese colonial era, when many indigenous people were forbidden from using kanuragan (secret ritual initiation tied to local cosmological practices and cults used by the Javanese) or pencak silat in their activities. As a result, many Keraton soldiers disguised themselves as ordinary residents by performing martial arts activities accompanied by jedor or flute music. This form of dance is performed with dancers who form a straight line and are accompanied by loud rhythmic music that is energetic and brimming with passion.

However, the emergence of UUHC was not accompanied by the awareness and understanding of both artists and local governments towards the protection of Copyrights for the Topeng Ireng dance art itself. Each region has its own treatment pattern in protecting dance works in their area. For this reason, it is necessary to identify the protection of dance works, especially the concept and efforts to protect the art of Topeng Ireng dance 
in Magelang.

\section{RESEARCH METHODOLOGY}

This study uses empirical juridical research with primary data in the form of field data obtained from interviews with the Topeng Ireng Dance Community, the Education and Culture Office of Magelang Regency, and the Association of Indonesian Intellectual Property Centers (ASKII). Secondary data was obtained from primary legal materials in the form of Copyright Law of 2014 and Law Number 5 of 2017 concerning the Cultural Development. The data obtained were then analyzed qualitatively and presented descriptively.

\section{RESULT AND DISCUSSION}

\subsection{State of the Art Protection of Dance Works}

The existence of dance arts has an impact on improving the economy in Indonesia. According to Aziz Abdul Muh. (2017), traditional dance art has an essential role in community activities where the dance grows and develops. Dance can make the community recognized as a regional characteristic, and as a medium in cultural communication. Research conducted by Ramadhan (2020) stated that the protection of copyrighted works owned by indigenous Indonesians has been determined by the Ministry of Education and Culture of the Republic of Indonesia as Indonesian Intangible Cultural Heritage. As one of the traditional art forms in Lampung, the melinting dance is protected by the Lampung Provincial Government by making regulations concerning the Protection of the Intellectual Works of the Lampung Community. The ideal role of the Lampung Provincial government is to include subjects and extracurriculars into the school program, so that today's children do not forget the nature of their ancestral cultural heritage. As for the factual role, namely as an effort to protect and preserve the melinting dance, it is carried out by holding activities such as the Traditional Festival, in various activities to be known by the public and also to show that the existence of the Melinting Dance is maintained.

Protection of dance works in other areas is also carried out by the Bysari Village Government, Banyuwangi Regency. According to research from Haerah and Argarini (2017), the village government plays a role by following the principles of the Law on Villages No. 6 of 2014 through community participation in building and preserving villages as well as increasing village income and prospering the lives of rural communities. The village government is also cooperating with the Tourism Office so that the local wisdom of the village can still be preserved and seen by the wider community. Research conducted by Prajawati (2020), the Kebumen local government protects the art of lawet dance through the performance of lawet dance on the anniversary of Kebumen district, the opening of the Sports and Arts Week and the inauguration of the Candradimuka football stadium. This momentum is when Lawet dance is at its peak of popularity. In the end, Lawet dance was used as a local content courses for elementary schools in Kebumen district. Research conducted by Pratama, Susilowati and Prananingtyas (2012), the efforts of the Regional Government of Tegal Regency in protecting the art of Topeng Gaya dance is the issuance of a Decree of the Regent of Tegal on February 1, 2005 with Number: 420/0141/2005 concerning the Inauguration of 6 (six) types of Mask Dance in Tegal Regency, holding an Art Parade in Tegal Regency, and making cassettes and CDs of all Tegal Style Mask Dances by the Tegal Regency Tourism and Culture Office. To date, no research has been conducted that analyzes the conception and protection of Topeng Ireng Dance in Magelang Regency.

\subsection{Topeng Ireng Dance as a Copyrighted works and Traditional Cultural Expression (EBT)}

The Topeng Ireng dance is a traditional Magelang art that was born in the 90s from a Magelang artist by the name of Dayakan. The mention of the Mask Ireng dance itself was only established in the $2005 \mathrm{~s}$ because it was taken from the color of the costume and make-up which was jet black so that ordinary people were more familiar with the term Topeng Ireng. The hallmark of the Topeng ireng or Dayakan lies in the costumes of the dancers decorated with feathers similar to the crown of Indian tribal chiefs, while the lower costume is like Dayak clothing, tufted skirts. The fame of the Dayak in the Javanese tribe, especially in Magelang is based on the costumes used by the dancers, the lower clothes used by the dancers resemble the traditional clothes of the Dayak tribe. Topeng Ireng dance has simple movements and no complicated gestures. The main point of this dance is cohesiveness. This dance art is staged with dancers who line up straight and accompanied by loud rhythmic music and energetic and full of enthusiasm. The Topeng Ireng dance is accompanied by simple musical instruments such as gamelan, drums, flying, bende, and tambourines as their signature musical instruments.

As an art, the mask dance is a work that needs to be protected by copyright instruments. There is a principle of protection in copyright that is automatic without the need for registration. This principle is called the Automatic Protection Principle. However, automatic protection is not necessarily given to the creator, but is required to fulfill a requirement called the Standard of Copyright Ability. The existence of automatic protection owned by copyright can apply if a work has met the requirements of authenticity and have a real form. Thus, the standard of copyright ability is used as a measure to determine whether a work can be protected by a copyright instrument or not. 
Based on the results of interviews that have been conducted with Mr. Supadi Haryanto as Chairman of the Topeng Ireng Dance Community, in terms of authenticity, the art of mask ireng dance has been entrenched from generation to generation but it is not known who the original creator is so that the authenticity of the Topeng Ireng dance is based on recognition from the community in Magelang Regency.

According to Article $38 \mathrm{UUHC}$, if a copyrighted work is not known to the author, then the state holds the Copyright for Traditional Cultural Expressions (EBT). The categorization of the Topeng Ireng dance as EBT refers to the explanation of Article 38 paragraph (1) UUHC which reads:

What is meant by "traditional cultural expressions" includes one or a combination of the following forms of expression:

a. verbal textual, both oral and written, in the form of prose or poetry, in various themes and contents of the message, which can be in the form of literary works or informative narratives;

b. music, including, inter alia, vocal, instrumental, or a combination thereof;

c. movement, including, among other things, dance;

d. theater, which includes, among others, puppet shows and folk plays;

e. fine arts, both in two-dimensional and three-dimensional forms made of various materials such as leather, wood, bamboo, metal, stone, ceramics, paper, textiles, and others or a combination thereof; and

f. traditional ceremonies.

There are legal consequences for the state if it holds Copyrights for the Topeng Ireng dance art work, namely the state is obliged to inventory, maintain, and maintain Traditional Cultural Expressions in accordance with the rules regulated in Government Regulations. In this case, the government issued a more general regulation, namely Law Number 5 of 2017 concerning the Cultural Development (Cultural Development Law). This law has regulated the role of the Regional Government to take part in advancing culture in Indonesia, one of which is the art of dance.

Against the second standard of Copyright Ability, which is realized in real form, the art of mask dance is manifested in the form of movements and musical accompaniment which is documented in video and stored by the performers of the Topeng Ireng dance. Historically, the musical accompaniment of the Topeng Ireng dance only uses drums and gendhig, campur, tambourines, as their distinctive musical instruments. Around 2005 and above in collaboration with gamelan music, flute. Because following the times and the demands of the audience, it is combined again with music and added with dangdut music, Malay style and even rock music. The documentation can be categorized as a tangible manifestation of fulfilling the Standard of Copyright Ability. Therefore, The Topeng Ireng Dance can be categorized as a copyrighted works and Traditional Cultural Expression (EBT).

\subsection{Concepts and efforts to protect the law against the Topeng Ireng dance in Magelang}

According to Philipus M. Hadjon, the concept of legal protection is the protection of dignity and human rights, which are owned by legal subjects based on legal provisions from arbitrariness. The concept of legal protection is divided into two, namely: preventive legal protection and repressive legal protection. Preventive legal protection aims to prevent disputes from occurring, which directs government actions to be careful in making decisions based on discretion, while repressive protection aims to resolve disputes, including their handling in the judiciary.

Based on interviews conducted with Mr. Mantep from the Department of Education and Culture, the local government of Magelang Regency carried out bookkeeping and data collection before any claimed from other parties. Data recording and bookkeeping is carried out by the Education and Culture Office of Magelang Regency once every 5 (five) years. Updating, stipulating, and accounting for data is carried out through an endorsement letter issued by the education and culture office. In addition, another effort made by the Mgelang Regency government is to carry out a promise strategy through a declarative way by being announced in front of the general public. Recording or data collection is also carried out by the government to find out how many arts exist in Magelang district and to know the progress of the arts by direct surveys to art organizations. According to Mr. Mantep, this effort is considered effective enough to provide EBT protection in the form of the Topeng Ireng dance. Based on the Article 16 of the Cultural Development Law, this effort is relevant and in line with the obligations of the Regional Government in making an inventory of EBT. However, the Regional Government of Magelang Regency should still register the Copyright for the EBT of the Topeng Ireng dance art. Copyright registration can serve as evidence in court. When a copyright dispute occurs, one of them is a cultural claim from another party.

In the protection of repressive laws, until now the Magelang Regency Government has not made special efforts. This condition is due to the absence of cases of claims of EBT for the mask of ireng dance by other parties. However, according to Mr. Mantep, if one day there is a claim for the EBT of Topeng ireng dance, the Regency Government will immediately act by filing a lawsuit to the Commercial Court accompanied by concrete evidence in the form of publication videos, history books of the establishment of the Topeng Ireng, activity 
inventory books and witnesses - witnesses from the mask dance community ireng.

\subsection{The Efforts of the Magelang's Regional Government in Optimizing the Art of Topeng Ireng Dance to support the Cultural Development}

Concretely, several efforts made by the Regional Government of Magelang Regency in optimizing the Topeng Ireng dance are divided into 4 (four) aspects in accordance with the Law for the Advancement of Culture, namely protection, development, utilization and guidance.

Protection efforts include collecting data on the types of arts that exist in Magelang Regency, namely by inventorying in the bookkeeping model and issuing idakep cards (a type of issuance letter/sign that the art community has been registered with the Regional Government). The development effort was carried out by inviting the younger generation to get to know the art of the mask dance ireng through the watching of a profile video of Magelang Regency at the anniversary of Magelang Regency and providing opportunities for the performers of the Topeng Ireng dance to improvise the movements of the Topeng Ireng dance.

Utilization efforts are carried out by involving the Topeng Ireng dance community in cultural and dance competitions. The Magelang Regency Government held an Art Parade throughout Magelang Regency. The mechanism, from the many art communities, is taken the best and sent to events/contests, for example the Central Java Parade, performances at TMII, at the Denpasar Cultural Week, Bali, Kulonprogo, Sleman, Kendal, and others. These events start from the regional level to the national level. In addition, the Magelang Regency Government provides publicity for the art of the Topeng Ireng dance through live streaming on the Magelang Regency Government's YouTube channel. The live streaming is held every time there is an event, including the Anniversary of Magelang Regency, after the Indonesian Republic Anniversary ceremony, and separate dance competitions such as art competitions throughout Magelang Regency, Art competitions throughout Central Java, and others. In addition, publications are also carried out live streaming on the YouTube channel of the Magelang Regional Government every Mungkid Anniversary on March 22.

The coaching effort is conducted by educating the lower-level dance community to maintain and enhance their talents in order to qualify for the upper level to represent art festivals. The guidance is in the form of improving musical accompaniment, choreography, and preserving the Topeng Ireng with the aim of becoming a superior art in Magelang Regency. In addition, the Magelang Regency Government provides financial assistance for each art using social assistance grants, and provides assistance for each art in the form of coaching money.

\subsection{The Efforts of the Magelang's Regional Government in Optimizing the Art of Topeng Ireng Dance to support the Cultural Development}

According to Soerjono Soekanto, there are five factors that can influence the success of law enforcement and protection, namely: Regulatory factors, law enforcement, facilities or facilities that support law enforcement, society, and culture. These five factors are closely related and are the essence of law enforcement, which is very relevant to the protection of the law itself. In addition, these five factors are also a measure of the effectiveness of law enforcement.

The factors that influence the implementation of copyright protection for the Topeng Ireng dance in Magelang are presented in Table 1.

Table 1. Factors Affecting the Implementation of Copyright Protection for Topeng Ireng Dance

\begin{tabular}{clll}
\hline No & Indicator & \multicolumn{1}{c}{ Implementation } \\
\hline $\mathbf{1}$ & Regulation & $\begin{array}{l}\text { From the regulatory aspect, UUHC and the Cultural Development Law have provided } \\
\text { comprehensive provisions in protecting works of art, especially dance. }\end{array}$ \\
\hline $\mathbf{2}$ & $\begin{array}{l}\text { Law } \\
\text { enforcer }\end{array}$ & $\begin{array}{l}\text { There is still minimal and limited understanding of the state apparatus at the Magelang } \\
\text { district level regarding the importance of Copyright and the promotion of culture. Most } \\
\text { agencies still think that culture is solely related to aspects of expression that can be used to } \\
\text { strengthen the tourism agenda. The effect of the tourism industry is that the treatment of } \\
\text { objects for the promotion of oral traditions, rites, and arts, must follow tourism formulas, } \\
\text { but emphasizes the principles of promotion such as development, protection, guidance, } \\
\text { development, and utilization. }\end{array}$ \\
\hline $\mathbf{3}$ & Facilities & $\begin{array}{l}\text { Factors of facilities and facilities, are highly dependent on human resources as carriers of } \\
\text { EBT and sources of funds. Based on the results of interviews, many independent arts use } \\
\text { the request system and the money they get is partly for members and partly for cash as } \\
\text { repairs for updating musical instruments or other improvements. The majority of dancers } \\
\text { rarely submit proposals for financial assistance because they have a strong life principle } \\
\text { because dancing is for fun and not for a profession. So, they indirectly provide cultural } \\
\text { wealth to the government. Their independent money can be obtained from dues for their } \\
\text { appearance. }\end{array}$ \\
\hline
\end{tabular}




\begin{tabular}{|c|c|c|}
\hline No & Indicator & Implementation \\
\hline 4 & Society & $\begin{array}{l}\text { Similar to law enforcement factors, the people who perform the Topeng Ireng dance do not } \\
\text { yet understand the urgency of protecting the art of dance. They assume that copyright } \\
\text { registration is only a form of legal. In addition, the performers of the Topeng Ireng art feel } \\
\text { that copyright registration is very complicated, time-consuming and expensive. In this } \\
\text { context, the performers of the Topeng Ireng dance do not know that the copyright of the } \\
\text { Topeng Ireng dance is held by the State and in accordance with the Cultural Development } \\
\text { Law, the state is obliged to protect the Topeng Ireng dance art. }\end{array}$ \\
\hline 5 & Culture & $\begin{array}{l}\text { Cultural factors are strongly influenced by the legal culture of the Indonesian nation which } \\
\text { adheres to the concept of an eastern legal culture that is communal rights, especially with } \\
\text { regard to intellectual property rights law which means togetherness. A person's property is a } \\
\text { common property of the community. This is different from the western culture which } \\
\text { adheres to a legal culture of individual rights which highly respects individual property } \\
\text { rights. }\end{array}$ \\
\hline
\end{tabular}

\section{CONCLUSION}

Based on the description above, the Topeng Ireng dance meets the requirements as a work and deserves copyright protection. The protection of the Topeng Ireng dance is in the form of preventive legal protection by taking inventory, development, utilization and guidance. Repressive legal efforts have not been carried out because until now, no claims have been found by other parties against the art of mask ireng. However, if this condition occurs, the local government of Magelang Regency will immediately act by filing a lawsuit to the Commercial Court accompanied by concrete evidence in the form of publication videos, history books of the establishment of the Topeng Ireng, activity inventory books and witnesses from the mask dance community. The factors that influence the implementation of the protection of the Toepng Ireng dance consist of regulatory factors, law enforcement, facilities or facilities that support law enforcement, society, and culture.

\section{References}

Astar, A. (2017) 'Perlindungan Hukum Terhadap Pengetahuan Dan Ekspresi Budaya Tradisional Untuk Meningkatkan Kesejahteraan Masyarakat Ditinjau Dari Undang-Undang No. 5 Tahun 2017 Tentang Pemajuan Kebudayaan Dan Undang- Undang No. 28 Tahun 2014 Tentang Hak Cipta', Journal Law Reform, 13(2), pp. 284-299.

Aziz Abdul Muh. (2017) 'Produk Seni Nusantara Dalam Konteks Ekonomi Kreatif’, Imaji, 15(1), pp. 24-36.

Djuhara, U. (2014) 'Pergeseran Fungsi Seni Tari Sebagai Upaya Pengembangan dan Pelestarian Kebudayaan', Jurnal Ilmiah Seni Makalangan, 1(2), pp. 99-117.

Haerah, K. and Argarini, Z. (2017) 'Peran pemerintah desa dalam melestarikan budaya tari Seblang (studi kasus di desa Olehsari kecamatan Glagah kabupaten Banyuwangi)', Jurnal Politico, 17(1), pp. 1-52. Available at: http://jurnal.unmuhjember.ac.id/index.php/POLITICO/article/view/735.

Hapsari, L. (2013) 'Fungsi Topeng Ireng di Kurahan Kabupaten Magelang', Jurnal Pengetahuan dan Pemikiran Seni, 2, pp. 138-144.

Najah, A. and Malarsih, M. (2019) 'Pelestarian Tari Pesta Baratan di Kecamatan Kalinyamatan Kabupaten Jepara', Jurnal Seni Tari, 8(1), pp. 12-20. doi: 10.15294/jst.v8i1.30770.

Prajawati, Y. Ti. (2020) 'Peran Pemerintah Daerah Kebumen dalam Melestarikan Tari Lawet sebagai Sarana Memperkenalkan Komoditas Lawet dari Kabupaten Kebumen', Media Bina Ilmiah, 15(1), pp. 3831-3840. Available at: http://mpoc.org.my/malaysian-palm-oil-industry/.

Pratama, A. P. S., Susilowati, E. and Prananingtyas, P. (2012) 'Upaya Pemerintah Daerah Kabupaten Tegal dalam Rangka Melindungi Kesenian Tari Topeng Khas Kabupaten Tegal', Diponegoro Law Review, 4(1), pp. 1-10.

Ramadhan, R. A. (2020) 'Perlindungan warisan budaya seni tari melinting masyarakat adat lampung dalam perspektif sistem hukum kekayaan intelektual', Indonesian Private Law Review, 1(1), pp. 23-34. doi: 10.22146/JH.6183.2. 